\title{
SCABIES : PENYEBAB, PENANGANAN DAN PENCEGAHANNYA
}

\section{Tias Pramesti Griana}

\author{
Jurusan Biologi \\ Fakultas Sains dan Teknologi \\ Universitas Islam Negeri Maulana Malik Ibrahim Malang \\ Email: tiaspram esti@yahoo.co.id
}

\begin{abstract}
Gudik or kudis is a kind of skin disease that could be found in people who living in crowded neighborhood, for examples slums area, Islamic boarding school, prison, military camp and hospital. Gudik could be infect all age, race, and social economic level. Many people do not know that the cause of gudik is mite which named Sarcoptes scabiei. According to Departemen Kesehatan Republik Indonesia, scabies ranked third of the twelve of skin disease that most often arises. Until now, scabies is still neglected, and it becomes to be public health problems worldwide. As the transmission process is fast, misunderstanding of society about this disease makes difficult to eradicate scabies. Sarcoptes scabiei lives in stratum corneum of skin and eat cell fluids. Female mite digs tunnels under skin surfaces and lays its eggs. This mite activities cause rash on the skin and itch at night. Transmission of scabies can through direct or indirect contact with the patient. Drug of choice for scabies is still debatable. Although the results of therapy are effective, sulfur 5\%-10\%, benzyl benzoate, crotamiton 10\%, permethrin 5\% and ivermectin give bad side effect for patient. In vitro study showed the effectivity of tea tree 5\% (Melaleuca alternifolia), paste of neem leaves (Azadirachta indica) and turmeric (Curcuma longa), and anise (Pimpinella anisum) as scabicide. Prevention of scabies transmisstion is carried out by hygiene and treatment for all people who have direct contact with the patient.
\end{abstract}

Key word: gudik, scabies, Sarcoptes scabiei

\section{PENDAHULUAN}

Penyakit gudik atau kudis, merupakan penyakit kulit yang dapat di temui hampir di setiap pondok pesantren dan dianggap sebagai penyakit yang tidak berbahaya sehingga kurang mendapat perhatian baik dari penderita maupun orang-orang yang berada di sekitarnya (Badri, 2007; Yasin, 2009; Afraniza, 2011; Antariksa, 2012). Bahkan ada anekdot yang menyebar di kalangan para santri pondok pesantren, bahwa seorang santri belum disebut mondok jika belum terkena penyakit gudik. Sebenarnya penyakit gudik bukan hanya menyerang para santri di pondok-pondok pesantren, tetapi juga dapat ditemui pada lingkungan kumuh dan padat penduduk (Wardhana, et al, 2006; Rohmawati, 2010; Afraniza, 2011), penjara (Mannocci, et al, 2014), kamp militer (Hengge, et al, 2006; Raza,et al, 2009), bahkan rumah sakit (Arlian, 1989; Larrosa, et al, 2003). Penyakit gudik dapat menjangkiti semua orang pada semua umur, ras dan level sosial ekonomi (Raza et al. 2009).

Selama ini masyarakat awam mengira gudikan disebabkan oleh air, yang digunakan untuk konsumsi atau kebutuhan sehari-hari, telah tercemar. Banyak orang masih belum mengetahui bahwa penyebab gudikan adalah spesies tungau yang tidak dapat dilihat oleh mata telanjang. Spesies ini disebut sebagai Sarcoptes scabiei (var. hominis) dan penyakitnya disebut scabies (Wardhana, et al, 2006; Nugraheni, 2008).

Scabies memberikan masalah kesehatan secara global, karena 300 juta kasus terjadi setiap tahunnya di dunia. World Health Organization (WHO) menyatakan scabies merupakan salah satu dari enam penyakit parasit epidermal kulit yang terbesar angka kejadiannya di dunia (Ryan, 2010). Insiden di Amerika hampir mencapai 1 juta kasus per tahun. Rata-rata prevalensi kejadian scabies di Inggris adalah 2,27 per 1000 orang (laki-laki) dan 2,81 per 1000 orang (perempuan), dimana 1 dari 1000 orang datang ke pusat-pusat kesehatan dengan keluhan gatal yang menetap (Lassa, et al, 2011; Fuller, 2013).

Prevalensi scabies di Indonesia menurut Departemen Kesehatan Republik Indonesia pada tahun 2000 sebesar 4,60$12,95 \%$ dan penyakit scabies menduduki 
urutan ketiga dari 12 penyakit kulit tersering. Pada tahun 1997, pernah terjadi Kejadian Luar Biasa (KLB) scabies di Desa Sudimoro, Kecamatan Turen, Kabupaten Malang, dimana sebanyak 915 dari 1008 (90,8\%) orang terserang scabies. Perbandingan penderita lakilaki dan perempuan adalah $83,7 \%: 18,3 \%$ (Poeranto, et al, 1997).

Sampai saat ini scabies masih terabaikan sehingga menjadi masalah kesehatan yang umum di seluruh dunia (Heukelbach dan Feldmeier, 2006). Cepatnya proses penularan dan ketidakpahaman masyarakat akan penyakit ini menimbulkan sulitnya pemberantasan scabies. Penulisan review jurnal ini bertujuan untuk memberikan pemahaman bagi pembaca tentang penyebab, cara penularan, penanganan penyakit, dan pencegahannya.

\section{SEJARAH}

Scabies telah dikenal oleh manusia sejak lama. Bukti arkeologi dan gambar hieroglif dari zaman Mesir kuno menunjukkan bahwa scabies telah menyebabkan iritasi bagi manusia sejak 2.500 tahun yang lalu. Sedangkan pada abad pertengahan di Eropa (Yunani dan Romawi), penyakit ini dikenal sebagai gatal-gatal yang biasa terjadi pada orang yang tinggal di lingkungan kumuh dan sosial ekonomi rendah (Arlian, 1989; Burgess, 1994).

Aristoteles (384-322 SM) dipercaya sebagai orang pertama yang mengidentifikasi tungau penyebab scabies dengan menggambarkannya sebagai "kutu di dalam daging" dan menyebutnya dengan istilah "akari". Scabies juga telah disebutkan oleh berbagai penulis, termasuk seorang tabib yang berasal dari Arab, Abu Al Hasan Ahmad Al Tabari $( \pm 970 \mathrm{M})$, pendeta yang bernama Hildegard (1098-1179 M), dan tabib dari bangsa Moor, Avenzoar (1091-1162 M) (Ramos-e-Silva, 1998). Pada tahun 1678, Bonomo dan Cestoni menggambarkan secara akurat penyebab scabies di dalam sebuah surat yang ditujukan untuk Francesco Redi. Mereka menceritakan sifat alami parasit, cara penularan, kemungkinan penyembuhan penyakit tersebut, dan gambaran mikroskopik bentuk telur dan kutu dewasa Sarcoptes scabiei. Hasil karya Bonomo dan Cestoni ini diakui sebagai deskripsi akurat parasit penyebab penyakit infeksi yang pertama. Selanjutnya pada tahun 1868, Hebra mempublikasikan sebuah acuan untuk mengenali parasit penyebab scabies (Arlian, 1989; Burgess, 1994).

Celsus, tabib dari zaman Romawi kuno, merupakan orang yang pertama kali mempopulerkan sebutan "scabies" untuk penyakit tersebut. Kata scabies sendiri berasal dari bahasa Latin, yaitu scabere yang berarti menggaruk (Roncalli, 1987; Celsus, 2014). Sedangkan nama Sarcoptes scabiei berasal dari bahasa Yunani yaitu sarx (daging) dan koptein (menancap/memotong). Secara harfiah skabies berarti gatal pada kulit sehingga muncul aktivitas menggaruk kulit yang gatal tersebut. Saat ini istilah scabies berarti lesi kulit yang muncul oleh aktivitas tungau. Penambahan kata varian hominis menunjukkan merupakan spesies yang biasa menginfeksi manusia (Hee, 2005).

\section{KLASIFIKASI}

Spesies Sarcoptes scabiei (var. hominis) diklasifikasikan ke dalam filum Arthropoda yang masuk ke dalam kelas Arachnida, sub kelas Acari (Acarina), ordo Astigmata, dan famili Sarcoptidae. Beberapa famili tungau yang bersifat obligat parasit pada kulit antara lain Sarcoptidae (menginfeksi mamalia), Knemidokoptidae (menginfeksi burung/unggas), dan Teinocoptidae (menginfeksi kelelawar). Famili Sarcoptidae yang mampu menular ke manusia, yaitu Sarcoptes scabiei, Notoeders cati (host asalnya adalah kucing), dan Trixacarus caviae (host asalnya adalah marmut) (McCarthy, et al, 2004).

\section{MORFOLOGI}

Hanya ada satu spesies di dalam genus Sarcoptidae dan adanya beberapa varian di dalam spesies akibat terjadinya interbreeding yang terus menerus antara populasi tungau yang menginfestasi manusia dan hewan. Spesies tungau Sarcoptes scabiei pada tiap jenis varian hanya berbeda dalam hal ukuran sedangkan morfologinya sulit untuk dibedakan (Wardhana, et al, 2006). Menurut Bandi dan Saikumar (2012) terdapat 15 varietas atau strain tungau yang telah diidentifikasi dan dideskripsikan secara morfologi tidak berbe da tetapi secara fisiologi dan genetik berbeda.

Tungau Sarcoptes scabiei berwarna putih krem dan tubuhnya simetris bilateral berbentuk oval yang cembung pada bagian dorsal dan pipih pada bagian ventral. Warna 
tungau jantan lebih gelap daripada betina. Permukaan tubuhnya bersisik dan dilengkapi dengan kutikula serta banyak dijumpai garisgaris paralel yang berjalan transversal (Wardhana, et al, 2006). Tungau dewasa mempunyai empat pasang tungkai berwarna coklat yang mengeras dan terletak pada thoraks. Thoraks dan abdomen menyatu membentuk idiosoma, segmen abdomen tidak ada atau tidak jelas. (Sterling, et al, 1992; Walton dan Currie, 2007) Terdapat enam atau tujuh tonjolan seperti sepasang tulang belakang pada permukaan dorsal tubuh dan dipenuhi setae. Kepalanya terdapat mulut yang khas disebut capitulum, dan dibagian abdomen terdapat anus. Spesies tungau ini tidak memiliki mata (Arlian, 1989).

Sarcoptes scabiei betina dewasa berukuran panjang sekitar $0.3-0.5 \mathrm{~mm}$ dan lebar sekitar $0,3 \mathrm{~mm}$, sedangkan yang jantan berukuran panjang sekitar $0.25 \mathrm{~mm}$ dan lebar $0,2 \mathrm{~mm}$. Ukuran tungau betina pada karnivora lebih kecil $(0.32-0.39 \times 0.25-0.3 \mathrm{~mm})$ daripada tungau pada manusia (var. hominis) (0.39 - 0.5 x $0.29-0.42 \mathrm{~mm}$ ) (Arlian, 1989; Sterling et al, 1992; McCarthy, et al, 2004;
Wardhana, et al, 2006; Walton dan Currie, 2007).

Larva Sarcoptes scabiei memiliki 6 kaki sedangkan nimfa dan dewasa memiliki delapan kaki. Perbedaan nimfa dan tungau dewasa adalah ukuran nimfa yang lebih kecil. Ujung sepasang kaki pertama dan kedua pada jantan dewasa didapatkan alat penghisap (pulvilli) sedangkan pada betina didapatkan setae yang panjang. Baik jantan maupun betina memiliki berbentuk seperti cakar yang berguna untuk mencengkeram kulit inang yang ditinggalinya (Arlian, 1989; Sterling, et al, 1992; Walton dan Currie, 2007; CDC, 2010). Sarcoptes scabiei memiliki sifat ectothermic, yaitu suhu tubuhnya dapat berubah-ubah mengikuti suhu lingkungan tempat tinggalnya (Ihrig, 2013).

Telur Sarcoptes scabiei berbentuk oval berukuran panjang $0.1-0.15 \mathrm{~mm}$. Sekitar 10 25 buah telur diletakkan memanjang membentuk garis horizontal sesuai jalur terowongan yang digali oleh tungau betina. Dari sekian banyak telur yang dihasilkan tungau betina, tidak lebih dari $10 \%$ yang akan menetas menjadi tungau dewasa (Arlian, 1989; CDC, 2010).

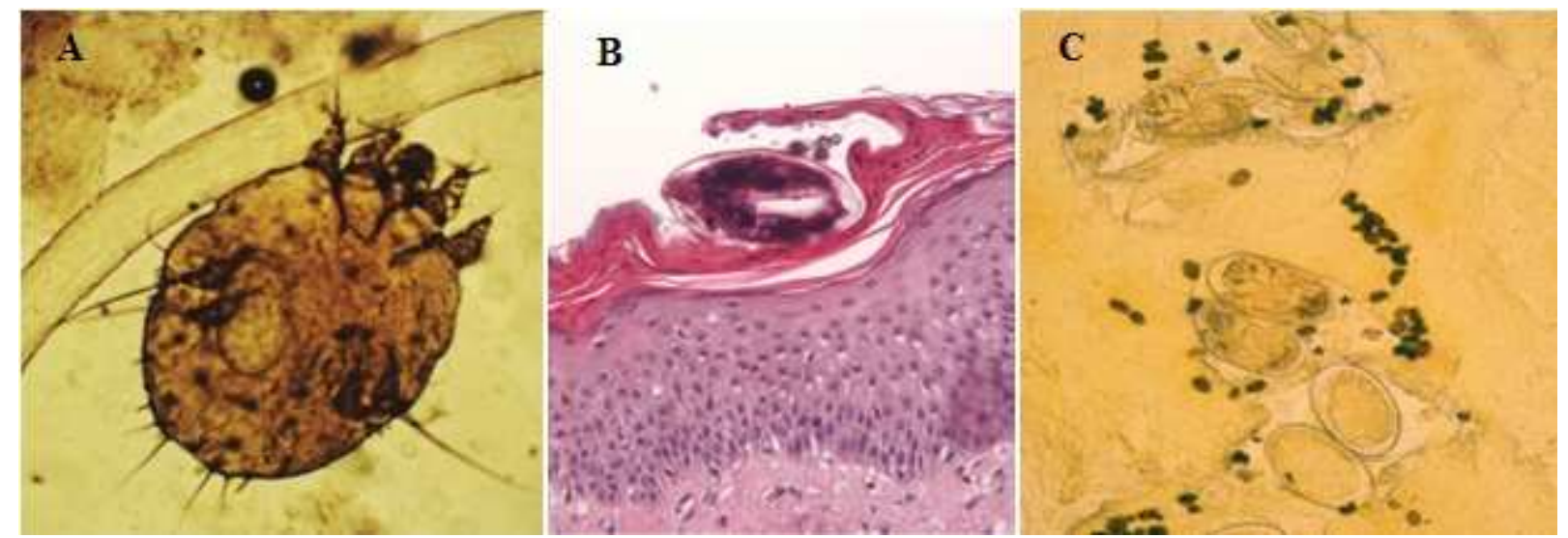

Gambar 1. A.Tungau Sarcoptes scabiei (var. hominis) betina dengan perbesaran 400x. (Walton \& Currie, 2007). B. Telur, nimfa* Sarcoptes scabiei (var. hominis) dan skibala (butiran feses) pada kerokan kulit yang ditetesi $\mathrm{NaOH}$ 10\% (Hengge, et al, 2006). C. Histologi kulit : tampak infestasi sarcoptes scabiei pada stratum korneum $(\mathrm{MDCH}, 2005)$

\section{SIKLUS HIDUP}

Sarcoptes scabiei tinggal di dalam stratum korneum (lapisan tanduk) kulit dan memakan cairan sel. Tungau menggali hanya dilapisan bagian atas kulit dan tidak pernah sampai di bawah stratum korneum. Terowongan yang dihasilkan tampak sebagai garis tipis yang berkelok-kelok yang berwarna abu-abu atau seperti kulit dengan panjang dapat mencapai lebih dari $1 \mathrm{~cm}$ (CDC, 2010).

Siklus hidup Sarcoptes scabiei dari telur hingga menjadi tungau dewasa memerlukan waktu 10-14 hari sedangkan tungau betina mampu hidup pada inangnya hingga 30 hari (Wardhana, et al, 2006; CDC, 2010). Tungau betina menggali terowongan di bawah permukaan kulit dan meletakkan 2 - 3 
telur setiap harinya selama 6 hari berturutturut, sehingga menyebabkan timbulnya papule pada kulit. Telur akan menetas setelah 2 - 3 hari (Arlian, 1989; CDC, 2010).

Perkembangan instar meliputi telur, larva, protonimfa, dan tritonimfa. Setelah menetas, larva bermigrasi ke permukaan kulit dan menggali area stratum korneum yang masih utuh menghasilkan terowongan pendek yang hampir tidak terlihat yang disebut sebagai moulting pounch (kantung untuk berganti kulit). Setelah berumur 3-4 hari, larva Sarcoptes scabiei, yang berkaki 3 pasang akan berganti kulit, menghasilkan protonimfa berkaki 4 pasang. Kemudian protonimfa akan berganti kulit lagi menjadi tritonimfa sebelum benar-benar menjadi tungau dewasa. Larva dan nimfa biasanya dapat ditemukan di dalam moulting pounch atau pada folikel rambut. Tritonimfa akan menjadi dewasa dan berubah spesifik menjadi jantan atau betina dalam waktu 3-6 hari. Setelah dewasa, tungau akan segera keluar dari moulting pounch ke permukaan kulit untuk mencari area stratum korneum yang masih utuh dan membuat terowongan kembali (Arlian, 1989; Wardhana, et al, 2006; CDC, 2010; Ogg, 2014).

Tungau jantan dewasa jarang ditemukan di permukaan kulit, karena mereka berada di dalam lubang sempit dan makan sampai mereka siap untuk kawin. Setelah siap kawin, tungau jantan dewasa akan mencari tungau betina dewasa yang berada di dalam moulting pounch. Perkawinan terjadi ketika tungau jantan dewasa melakukan penetrasi ke dalam moulting pounch berisi tungau betina dewasa fertil. Perkawinan hanya terjadi sekali. Meskipun masih diperdebatkan, tetapi diyakini bahwa tungau jantan akan mati setelah melakukan perkawinan (Arlian, 1989; CDC, 2010; Ogg, 2014).

Tungau betina yang mengandung telur akan meninggalkan moulting pounch dan berada di permukaan kulit sampai menemukan tempat yang cocok untuk menggali terowongan permanen untuk meletakkan telurtelurnya. Setelah bertelur, tungau betina dewasa akan hidup sampai 1-2 bulan sebelum kemudian mati (CDC, 2010).

\section{INFESTASI, DAYA TAHAN HIDUP DAN PENULARAN PADA INANG}

Diluar tubuh inang, Sarcoptes scabiei dapat bertahan hidup selama 24-36 jam dalam suhu ruangan $\left(21^{\circ} \mathrm{C}\right)$ dan dengan kelembaban
$40 \%-80 \%$. Pada suhu yang lebih rendah (10$15^{\circ} \mathrm{C}$ ) dengan kelembaban yang lebih tinggi Sarcoptes scabiei dapat bertahan hidup lebih lama (Arlian, 1989). Meskipun tidak memiliki mata, Sarcoptes scabiei menggunakan rangsangan bau dan suhu untuk mengenali tubuh inang (Walton dan Currie, 2007).

Penularan scabies mudah terjadi saat orang sehat kontak langsung dengan penderita dalam jangka waktu yang lama, sehingga sering terjadi penularan secara cepat dalam sebuah keluarga maupun dalam sebuah komunitas yang tinggal di lingkungan padat penghuninya. Penularan juga dimungkinkan melalui hubungan seksual, karena adanya kontak kulit secara langsung dari penderita ke orang sehat lainnya (Hengge, et al, 2006).

Dari penelitian yang dilakukan oleh Mellanby (1941) pada 272 relawan yang memakai pakaian penderita scabies selama 7 hari dan hanya ditemukan 4 relawan positif tertular scabies. Keempat relawan tertular dari pederita scabies berat yang telah terinfeksi ribuan tungau (hiperinfestasi) seperti pada Norwegian scabies. Meskipun Mellanby berpendapat bahwa penularan melalui pakaian, haduk ataupun kasur yang telah digunakan penderita scabies sangat kecil peluangnya, tetapi untuk jenis penyakit scabies dengan hiperinfestasi akan mudah terjadi (Oakley, 2009).

Penelitian lain menyebutkan bahwa varian jenis tungau scabies pada manusia mampu bertahan hidup selama tiga hari di luar inang dan mampu menginfestasi para pekerja laundry, sedangkan varian jenis tungau scabies pada hewan terbukti mampu menginfestasi manusia namun diduga tidak mampu menyelesaikan siklus hidupnya (Wardhana, et $a l, 2006)$. Penularan scabies hanya terjadi jika tungau yang ditransfer dari penderita ke orang sehat adalah Sarcoptes scabiei betina yang mengandung telur fertil (CDC, 2010). Satu bulan setelah infestasi, jumlah tungau di dalam lapisan kulit mengalami peningkatan. Sebanyak 25 ekor tungau betina dewasa ditemukan pada lima puluh hari setelah infestasi dan menjadi lima ratus ekor setelah seratus hari kemudian (McCarthy, et al, 2004).

\section{MANIFESTASI KLINIS}

Umumnya predileksi infestasi tungau adalah lapisan kulit yang tipis, seperti di selasela jari tangan dan kaki, pergelangan tangan, siku bagian luar, lipatan ketiak bagian depan, 
dada, periareolar (khusus pada wanita), punggung, pinggang, pusar, bokong, selangkangan, sekitar alat kelamin, dan penis (khusus pada pria). Pada bayi dan anak-anak dapat juga ditemukan ruam pada kulit kepala, wajah, leher telapak tangan, dan kaki (Arlian, 1989; McCarthy, et al, 2004; CDC, 2010).

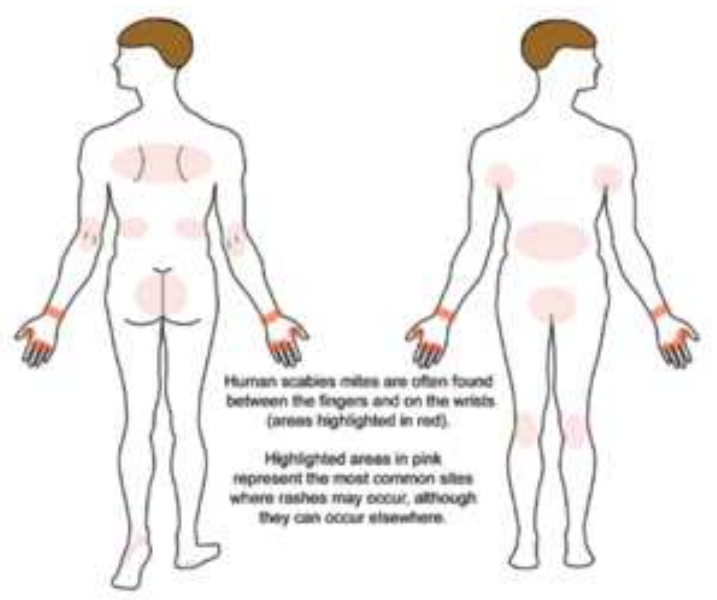

Gambar 2. Predileksi (area) infestasi tungau Sarcoptes scabiei pada tubuh manusia (area pada gambar yang berwarna merah muda) (CDC, 2010)

Sarcoptes scabiei memerlukan waktu kurang dari tiga puluh menit untuk masuk ke dalam lapisan kulit. Gejala klinis akibat infestasi tungau Sarcoptes scabiei adalah timbulnya ruam pada kulit dan rasa gatal (pruritus) terutama pada malam hari (McCarthy, et al, 2004). Ruam pada kulit berawal dengan terjadinya papulae eritrema (penonjolan kulit tanpa berisi cairan, berbentuk bulat, berbatas tegas, berwarna merah, ukuran $<1 \mathrm{~cm}$ ) yang terus berkembang menjadi vesicle atau pustule (penonjolan kulit berisi cairan atau nanah). Adanya terowongan di bawah lapisan kulit merupakan ciri khas dari infestasi tungau ini (McCarthy, et al, 2004; Engelman, et al, 2013).

Gejala gatal (pruritus) akan timbul lebih dari 3 minggu setelah infestasi tungau ke dalam kulit. Rasa gatal terjadi menyeluruh baik pada kulit tempat infestasi tungau maupun tidak. Keparahan gejala gatal-gatal dan ruam yang timbul tidak berhubungan dengan jumlah tungau yang menginfestasi kulit. Hal ini diduga akibat sensitifitas kulit terhadap tubuh tungau dan hasil ekskresi dan sekresi tungau (saliva, telur dan skibala). Sarcoptes scabiei mampu memproduksi substansi proteolitik (sekresi saliva) yang berperan dalam pembuatan terowongan, aktivitas makan, dan melekatkan telurnya pada terowongan tersebut. Reaksi hipersensitifitas tipe IV dapat menimbulkan nodul (bentuk papule dengan ukuran yang lebih besar) dan bulla (bentuk vesicle dengan ukuran yang lebih besar) pada area di mana tidak ditemukan tungau pada kulit (McCarthy, et al, 2004; Engelman, et al, 2013). Nodul biasanya ditemukan di daerah selangkangan, bokong, dan pusar (Walton dan Currie, 2007).

Pada beberapa kasus, ruam, dan rasa gatal pada penderita scabies dapat menetap sampai beberapa minggu setelah pengobatan. Hal ini dimungkinkan karena tubuh tungau yang mati masih berada di bawah permukaan kulit. Nodul pada kulit juga dapat menetap sampai beberapa bulan setelah pengobatan (Walton dan Currie, 2007). Akibat terbukanya lapisan stratum korneum menyebabkan bakteri mudah menginfeksi kulit. Keadaan ini disebut scabies dengan infeksi sekunder. Bakteri yang biasanya menyebabkan infeksi sekunder adalah Streptococcus pyogenes dan Staphylococcus aureus (Engelman, et al., 2013). 


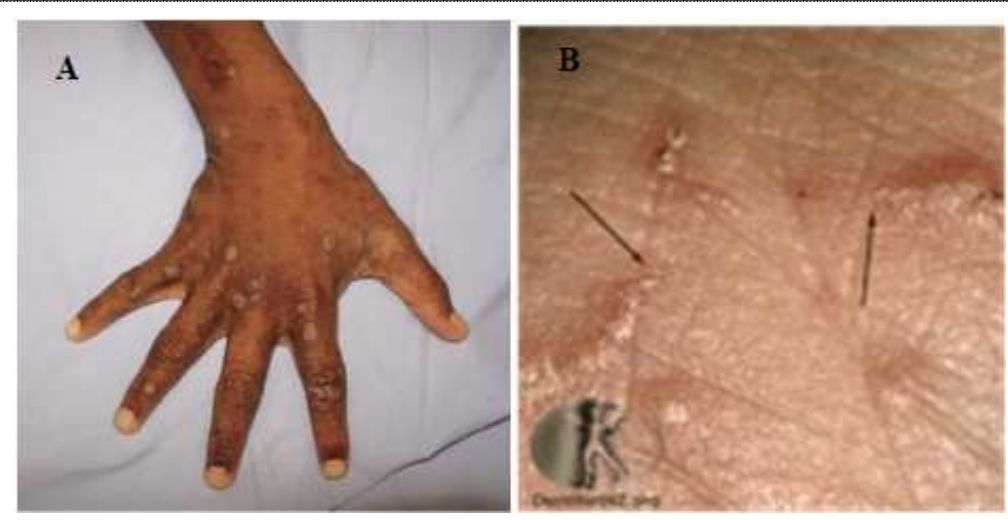

Gambar 3. A. Scabies dengan infeksi sekunder. Tampak papule dan pustule (Walton \& Currie, 2007). B. Tampak terowongan pada kulit (tanda panah) (Oakley, Scabies, 2013)

\section{PENGOBATAN}

Terapi Scabies dilakukan dengan memberikan skabisida, tetapi sampai saat ini obat pilihan yang paling tepat masih dalam perdebatan. Salep sulfur 5\% - 10\% telah digunakan selama satu abad dengan hasil yang memuaskan. Salep sulfur terdiri dari campuran sulfur dan jeli petroleum atau krim dingin. Campuran ini diberikan secara topikal pada malam hari selama tiga malam (Oakley, Scabies, 2013). Efek samping penggunaan sulfur adalah menyebabkan iritasi kulit, kotor, dan berbau, membutuhkan penggunaan yang berulang-ulang sehingga tidak disukai oleh penderita. Maka saat ini salep sulfur sudah tidak digunakan lagi (McCarthy, et al, 2004).

Benzyl benzoate, bentuk ester dari asam benzoate dan benzyl alcohol, merupakan hasil isolasi dari bahan alam, disebut sebagai balsam dari Peru, dan telah digunakan secara efektif selama lebih dari 60 tahun dalam larutan 25\% (Ascabiol). Benzyl benzoate merupakan agen yang cepat bereaksi dan penggunaan dalam waktu singkat sudah cukup efektif, tetapi tetap disarankan penggunaan solusio ini selama 24 jam (Walton, et al, 2000). Efek samping iritasi kulit yang terjadi pada penggunaan benzyl benzoate hanya beberapa menit. Benzyl benzoate secara in vitro merupakan agen antiscabies yang sangat aktif dan menunjukkan penyembuhan yang sangat baik. Telah dilaporkan terjadinya efek samping dermatitis kontak alergika pada penderita yang menggunakan solusio ini tetapi hal ini jarang terjadi. Penelitian menunjukkan bahwa 383 penderita anak-anak yang menggunakan benzyl benzoate mengalami gangguan neurotoksik (Walker dan Johnstone, 2000). Meskipun gangguan neurotoksik yang timbul tidak dapat disimpulkan sebagai efek samping akibat penggunaan benzyl benzoate, disarankan dalam penggunaannya dilakukan pengenceran untuk menghidari adanya efek samping (McCarthy, et al, 2004).

Crotamiton $10 \%$ (Eurax) telah digunakan secara luas karena toksisitasnya yang rendah. Crotamiton $10 \%$ berhasil mengobati $50 \%$ - $70 \%$ penderita dengan efektif. Kekurangan obat jenis ini adalah memerlukan aplikasi berulang kali selama 5 hari untuk mendapatkan respon yang memuaskan (McCarthy, et al, 2004). Efek samping yang mungkin terjadi adalah iritasi kulit, dermatitis alergika yang menimbulkan rasa gatal, terbakar, ditusuk, dan ruam. Belum diketahui keamanannya untuk anak-anak dan wanita hamil (Walker dan Johnstone, 2000).

Gamma benzene hexachloride $1 \%$ (Lindane, Kwell, Quellada) merupakan insektisida organochlorine yang menunjukkan efek penyembuhan sebesar $98 \%$ pada penderita, meskipun pemberiannya hanya selama 6 jam. Lindane telah digunakan sejak lama, tetapi akhir-akhir ini dilaporkan terjadi peningkatan resistensi tungau terhadap obat tersebut. Lindane dapat diserap ke sistemik ketika diberikan secara topikal, khususnya pada kulit yang rusak. Absorbsi sistemik lebih besar pada bayi daripada anak kecil. Efek samping neurotoksik (kejang) telah dilaporkan terjadi pada bayi, anak-anak dan orang dengan luka terbuka pada kulit. Penggunaan Lindane juga berhubungan dengan efek samping anemia aplastik idiosinkratik sehingga produk ini ditarik dari peredaran (Walton dan Currie, 2007).

Permethrin 5\%, meskipun lebih mahal daripada agen yang lain, sekarang menjadi terapi pilihan di Australia, Inggris, dan Amerika. Permethrin merupakan insektisida 
sintetik pyrethoid turunan dari chrysanthemums yang mudah ditoleransi dan toksisitasnya rendah, sedikit diabsorbsi oleh kulit dan yang terabsorbsi langsung dimetabolisme oleh tubuh. Aplikasi topikal lebih baik efeknya dibanding dengan oral. Dari program pemberantasan scabies secara masal pada suku Aborigin di Australia utara, menunjukkan bahwa permethrin dapat menyembuhkan $90 \%$ penderita (Walton, et al, 2000). Pengobatan scabies selama 2 minggu dengan pemberian aplikasi ganda dari permethrin $2.5 \%$ cream sama efektifnya dengan pemberian aplikasi tunggal Tenutex emulsion. Setelah pengobatan diulang selama 4 minggu, tampak permethrin $2.5 \%$ menunjukkan hasil yang lebih baik dari pada Tenutex emultion (Goldust ${ }^{\mathrm{a}}$, et al, 2013). Pemberian secara tunggal pada malam hari hampir sama efektifnya dengan Lindane (Walker dan Johnstone, 2000).

Ivermectin adalah antibiotik lakton makrosiklik dari kelompok avermectin, yang berasal dari Actinomicetes yang hidup di tanah yaitu Streptomices avermectalis. Obat ini menunjukkan aktivitas spektrum luas terhadap nematoda maupun arthropoda. Obat ini digunakan secara luas untuk tungau sarcoptes pada hewan dan pada manusia. Ivermectin merupakan terapi pilihan untuk filariasis cacing Onchocerca volvulus dan nematoda Strongylus stercoralis, serta digunakan secara luas untuk Wucheria branchofti dan Brugia malayi (penyebab kaki gajah) (McCarthy, et $a l$, 2004). Dari penelitian yang bertujuan membandingkan efikasi antara ivermectin (oral dosis tunggal) dan Lindane lotion 1\% (topikal aplikasi ganda) menunjukkan bahwa ivermectin lebih efektif dibandingkan Lindane lotion 1\% (Goldust ${ }^{\mathrm{b}}$, et al, 2013). Di lain pihak, Huffam dan Currie (1998) membuktikan bahwa pemberian ivermectin dengan dosis berulang berhasil menyembuhkan penderita hiperinfestasi tungau Sarcoptes scabiei, meskipun setengah dari jumlah penderita yang sembuh mengalami kekambuhan setelah lebih dari 6 minggu.

Skabisida baru yang menjanjikan berasal dari sejumlah minyak esensial dimana terpenoid banyak digunakan sebagai komponen aktif primer. Penelitian secara in vitro menunjukkan bahwa minyak pohon teh (tea tree) 5\% yang berasal dari pohon Melaleuca alternifolia (Walton dan Currie, 2007), pasta dari daun mimba (Azadirachta indica) dan kunyit (Curcuma longa) (Biswas, et al,2002; Hashmat, et al, 2012), dan adas manis atau anis (Pimpinella anisum) (Duke, 2000; Rayburn, 2007) memiliki efek sebagai skabisida.

Hasil penelitian menunjukkan dari segi kesembuhan klinis, krim permetrin 5\% lebih efektif dibandingkan krim ekstrak biji mimba $10 \%$. Sedangkan dari segi hasil dermoskopis antara krim permetrin dan mimba tidak menunjukkan perbedaan bermakna (Zainal, et $a l, 2013)$. Meskipun disimpulkan bahwa krim ekstrak biji mimba 10\% tidak lebih efektif jika dibandingkan krim permetrin 5\%, pada penelitian yang dilakukan oleh Charles dan Charles (1992), menunjukkan bahwa penggunaan kombinasi daun mimba dan kunyit yang dibuat menjadi pasta dapat menyembuhkan scabies pada 814 penderita. Sebesar $97 \%$ dari kasus scabies dapat disembuhkan dalam 3-15 hari pengobatan.

\section{PENCEGAHAN}

Setiap orang yang tinggal dan kontak langsung bersama penderita harus diobati meskipun tidak timbul gejala gatal-gatal. Hal ini disebabkan gejala gatal baru timbul setelah beberapa minggu setelah infestasi tungau. Baju, sprei, sarung bantal, selimut handuk, saputangan, dan kain lainnya yang sebelumnya digunakan oleh penderita disarankan dicuci dengan air panas dan dijemur dibawah sinar matahari atau dry cleaned untuk membunuh tungau yang menempel sehingga tidak menjadi sumber penularan (Oakley, 2009).

\section{KESIMPULAN}

Scabies merupakan penyakit yang sulit ditangani baik dalam hal pengobatan maupun pencegahannya. Hal ini disebabkan karena tungau Sarcoptes scabiei dapat hidup diluar tubuh manusia dan masih mampu menginfeksi inang yang lain. Penelitian berbagai macam skabisida menunjukkan bahwa hampir seluruhnya memberikan efek samping pada penderita. Pengembangan penelitian terapi scabies berbahan dasar alam mulai dikembangkan. Berbagai macam spesies tanaman telah diketahui efektif menyembuhkan penderita. Hal yang penting diperhatikan dalam pencegahan penyebaran penyakit scabies adalah mengobati semua orang yang kontak langsung dengan penderita serta membersihkan semua barang dan pakaian 
yang sebelumnya digunakan oleh penderita dengan cara dicuci menggunakan air panas dan dijemur dibawah sinar matahari atau dry cleaned untuk membunuh tungau yang menempel.

\section{DAFTAR PUSTAKA}

Afraniza, Y. 2011. Hubungan Antara Praktik Kebersihan Diri dan Angka Kejadian Skabies di Pesantren Kyai Gading Kabupaten Demak. Skripsi yang diterbitkan , Fakultas Kedokteran Universitas Diponegoro. Semarang.

Antariksa, EH. 2012. Hubungan Personal Hygiene dengan Kejadian Skabies pada Kelompok Khusus (Santri) di Pondok Modern Muhammadiyah Paciran Kabupaten Lamongan. Skripsi yang diterbitkan. Program Studi Keperawatan Universitas Muhammadiyah Surabaya. Surabaya.

Arlian, LG. 1989. Biology, Host Relation, and Epidemiology of Sarcoptes Scabiei. Annual Review of Entomologi. 34:139-161.

Badri, M. 2007. Hygiene Perseorangan Santri Pondok Pesantren Wali Songo Ngabar Ponorogo. Media Litbang Kesehatan. XVII (2):20-28.

Bandi, KM, dan Saikumar, C. 2012. Sarcoptic Mange: A Zoonotic Ectoparasitic Skin Disease. Journal of Clinical And Diagnostic Research. Hal.1-2.

Biswas, K, Cattopadhyay, I, dan Banerjee, RK. 2002. Biological activities and medicinal properties of Neem (Azadirachta indica). Current Science. 821 (11), 1336-1345.

Burgess, I. (1994). Sarcoptes scabiei and scabies. Advances in Parasitology. 33:235-292.

Celsus, A C. 2014. Celsus De Medicina. (1. Loeb Classical Library edition, Ed.) Retrieved May 2, 2014, from Bill Thayer's:

http://penelope.uchicago.edu/Thayer/ E/Roman/Texts/Celsus/6*.html.

Diakses pada tanggal 5 Mei 2014. Pukul: 20.00 .

Centers for Disease Control and Prevention (CDC). 2010. Parasite-Scabies. Retrieved May 4, 2014, from Centers for Disease Control and Prevention: http://www.cdc.gov/parasites/scabies /biology.html. Diakses pada tanggal 5 Mei 2014. Pukul: 20.00.

Charles, V, dan Charles, S. 1992. The use and efficacy of Azadirachta indica ADR ('Neem') and Curcuma longa ('Turmeric') in scabies. A pilot study. Tropical Georgia Medicine , 44 (12), 178-181.

Duke, JA. 2000. The Green Pharmacy. Herbal Handbook. Rodale.

Engelman, D, Kiang, K, Chosidow, O, McCarthy, J, Fuller, C, Lammie, P, et al. 2013. Toward the Global Control of Human Scabies:Introducing the International Alliance for the Control of Scabies. PLOS Neglected Tropical Diseases. 7 (8):1-4.

Fuller, LC. 2013. Epidemiology of Scabies. Curr Opin Infect Dis. 26 (2):123126.

Goldust $^{\mathrm{a}}$, M, Rezaee, E, Raghifar, R, \& Naghavi-Behzad, M. 2013. Comparison of permethrin $2.5 \%$ cream vs. Tenutex emulsion for the treatment of scabies. Annual of Parasitology. 59 (1):31-35.

Goldust $^{\mathrm{b}}$, M, Rezaee, E, Raghifar, R, dan Naghavi-Behzad, M. 2013. Ivermectin vs. lindane in the treatment of scabies. Annual of Parasitology. 59 (1):37-41.

Hashmat, I, Azad, H, \& Ahmed, A. 2012. Neem (Azadirachta indica A. Juss) A Nature's Drugstore: An overview. International Research Journal of Biology Sciences. 1 (6):76-79.

Hee, RV. 2005. Jeremy Thriverius (15041554) : humanist doctor, born 500 years ago. Revue Médicale de Bruxelles. 26:475-478.

Hengge, UR, Currie, BJ, Jager, G, dan Schwartz, RA. 2006. Scabies : a ubiquitous neglected skin disease. Lancet Infectious Disease. 6:769779.

Heukelbach, J, dan Feldmeier, H. 2006. Scabies. Lancet. 367 (9524):17671774.

Huffam, SE, dan Currie, BJ. 1998. Ivermectin for Sarcoptes scabiei hyperinfestation. International Journal of Infectious Disease. 2 (3): 152-154. 
Ihrig, T. 2013. Sarcoptes scabiei. Retrieved May 2, 2014, from Animal Diversity Web: http://animaldiversity.ummz.umich.e du/accounts/Sarcoptes_scabiei/.

Diakses pada tanggal 5 Mei 2014. Pukul: 20.00 .

Larrosa, A, Cortes-Blanco, M, Martinez, S, Clerencia, C, Urdaniz, L, Urban, J, et al. 2003. Nosocomial outbreak of scabies in a hospital in Spain. Europe Surveillence. 8 (10):199-203.

Lassa, S, Campbell, MJ, dan Bennett, CE. 2011. Epidemiology of Scabies Prevalence in the U.K. From General Practice Record. The British Journal Of Dermatology. 164 (6):1329-1334.

Mannocci, A, Thiene, D, Semyonov, L, Boccia, A, \& Torre, G. 2014. A cross-sectional study on dermatological diseases among male prisoners in southern Lazio, Italy. International Journal of Dermatology. 53 (5):586-592.

McCarthy, JS, Kemp, D, dan Currie, BJ. 2004. Scabies : more than just an irritation. Postgraduate Medical Journal. 80:382-387.

Mellanby, K. 1941. The Transmission of Scabies. British Medical Journal. Hal.405-406.

Michigan Department of Community Health (MDCH). 2005. Scabies Prevention And Control Manual. Michigan: Michigan Department of Community Health.

Nugraheni, DN. 2008. Pengaruh Sikap Tentang Kebersihan Diri Terhadap Timbulnya Skabies (Gudik) Pada Santriwati Di Pondok Pesantren AlMuayyad Surakarta. Skripsi yang diterbitkan. Fakultas Ilmu Kesehatan Universitas Muhammadiyah Surakarta. Surakarta.

Oakley, A. 2013. Scabies. Retrieved May 7, 2014, from DermNet NZ : http://www.dermnetnz.org/arthropod s/scabies.html. Diakses pada tanggal 5 Mei 2014. Pukul: 20.00.

Oakley, A. 2009. Scabies.Diagnosis and Management. Best Practice Journal. (19):12-16.

Ogg, B. 2014. UNL Extension in Lancaster County.Insects, Spiders, Mice and More. Retrieved May 2, 2014, from
University Of Nebraska-Lincoln: http://lancaster.unl.edu/pest/resources /medicalmites.shtml. Diakses pada tanggal 5 Mei 2014. Pukul: 20.00.

Poeranto, S, Sardjono, TW, Hakim, L, Sanjoto, P, \& Rahajoe, S. 1997. Pengobatan dengan gamexan pada penderita scabiosis di pondok pesantren $\mathrm{Al}$ Munawwariyyah Sudimoro, Malang. Majalah Kedokteran Unibraw. 13 (2):69-73.

Ramos-e-Silva, M. 1998. Giovan Cosimo Bonomo (1663-1696): Discoverer of the etiology of scabies. International Journal of Dermatology. 37 (8):625630.

Rayburn, D. 2007. Let's Get Natural With Herbs. Huntsville: Ozark Mountain.

Raza, N, Qadir, S N, dan Agha, H. 2009. Risk factors for scabies among soldiers in Pakistan : case-control study. Eastern Mediterranean Health Journal. 15 (5):1105-1110.

Rohmawati, RN. 2010. Hubungan Antara Faktor Pengetahuan dan Perilaku dengan Kejadian Skabies di Pondok Pesantren Al-Muayyad Surakarta. Skripsi yang diterbitkan. Program Studi Kesehatan Masyarakat Fakultas Ilmu Kesehatan Universitas Muhammadiyah Surakarta. Surakarta.

Roncalli, RA. 1987. The history of scabies in veterinary and human medicine from biblical to modern times. Veterinary Parasitology. 25 (2):193-198.

Ryan, J. 2010. Frequency Rates and Locations of Scabies. Retrieved May 2, 2014, from Ezinearticles: http://ezinearticles.com/?Frequency-

Rates-and-Locations-of-

Scabies\&id $=5259228$. Diakses pada tanggal 5 Mei 2014. Pukul: 20.00.

Sterling, G, Janniger, C, Kihiczak, G, Schwartz, R, dan Fox, M. 1992. Scabies. Am Fam Physician, 46 (4), 1237-1241.

Walker, G, dan Johnstone, P. 2000. Interventions for treating scabies. Conchrae Database Syst Rev. 3.

Walton, SF, dan Currie, BJ. 2007. Problem in Diagnosing Scabies, a Global Disease in Human and Animal Populations. Clinical Microbiology Reviews. 20 (2):268-279. 
Walton, S, Myerscough, M, dan Currie, B. 2000. Studies in vitro on the relative efficacy of current acaricides for Sarcoptes scabiei var. hominis. Trans $R$ Soc Trop Med Hyg. 94 (1):92-96.

Wardhana, AH, Manurung, J, dan Iskandar, T. 2006. Skabies : Tantangan Penyakit Zoonosis Masa Kini Dan Masa Mendatang. WARTAZOA. 16 (1):4052.

Yasin. 2009. Prevalensi Skabies dan FaktorFaktor yang Mempengaruhinya pada Siswa-Siswi Pondok Pesantren Darul Mujahadah Kabupaten Tegal Provinsi Jawa Tengah Bulan Oktober Tahun 2009. Skripsi yang diterbitkan. Program Studi Pendidikan Dokter Fakultas Kedokteran Dan Ilmu Kesehatan Unversitas Islam Negeri Syarf Hidayatullah. Jakarta.

Zainal, N, Tabri, F, Muchtar, SV, dan Djawad, K. 2013. Efektivitas Krim Ekstrak Biji Mimba 10\% Pada Penderita Skabies. Pasca Sarjana Universitas Hasanudin. Makasar. 